\section{Heavy metals and woody plants - biotechnologies for phytoremediation}

\section{Capuana M}

Soil contamination by heavy metals is among the most serious danger for the environment, and new methods for its containment and removal are claimed, in particular for agricultural soils. Phytoremediation is an emerging, potentially effective technology applicable to restoration of contaminated soils and waters. Besides hyperaccumulator herbaceous plants, several woody species are now considered of interest to this aim. Many woody plants are fast growing, have deep roots, produce abundant biomass, are easy to harvest, and several species revealed some capacity to tolerate and accumulate heavy metals. Biotechnologies are now available for investigating this potential and enlarge the possibilities of exploitation of trees for remediation. The use of in vitro cultures, the role of bacteria and mychorrhizas, the powerful tool of genetic engineering, are some of the aspects focused in this paper that open prospects of global relevance for a better understanding of the processes related to the uptake of heavy metals by woody plants. In recent years significant progress has been made in identifying native plants and developing genetically modified tree plants for the remediation of heavy-metal polluted environment. Despite the intensive research developed in the last years, few field trials demonstrated the feasibility of the approach described, therefore much efforts should be addressed to this goal.

Keywords: Engineering, In vitro culture, Michorrhyzas, Pollution, Trees

\section{Introduction}

Pollution of soil and agricultural land is a complex and serious phenomenon that in recent decades has increased its negative effects on the environment. Transfer of toxic elements to human food chain is a concrete danger that has to be faced, taking into account the possibility for plants to accumulate and translocate contaminants to edible and harvested parts (Kloke et al. 1984, Renzoni et al. 1998, Dudka \& Miller 1999, McLaughlin et al. 1999, Puschenreiter et al. 2005). Traditional technologies for removal of pollutants can be successful in specific situations, but costs associated with these technologies are very high. There is an active effort to develop new, more cost-effective methods to remediate contamination of polluted soils, hence attention is now focusing on innovative biological technologies such as phytoremediation, based on the use of plants to extract, sequester and/or detoxify

Plant Genetics Institute, Italian National Council of Research, v. Madonna del Piano 10, I-50019 Sesto Fiorentino (Firenze, Italy)

(a) Maurizio Capuana

(maurizio.capuana@igv.cnr.it)

Received: Sep 01, 2010 - Accepted: Nov 22, 2010

Citation: Capuana M, 2011. Heavy metals and woody plants - biotechnologies for phytoremediation. iForest 4: 7-15 [online: 2011-01-27] URL: http://www.sisef.it/ iforest/show.php?id=555 pollutants (Salt et al. 1998). The development of phytoremediation technologies is continuing, involving transgenic and nontransgenic approaches, as well as different biological, technical, social, and economical aspects. Biotechnologies applied to investigating the remediation capability of woody plants are increasingly showing their efficacy, hence some aspects of their exploitation are presented here.

The exploitation of in vitro culture, the role of endophytic bacteria and mychorrizas, and the efforts to enhance uptake capacity and tolerance to heavy metals by genetic engineering are therefore considered in the following chapters.

\section{Woody plants and phytoremediation}

Twenty-five years ago, studies on phytoremediation techniques were rather scarce; now the scientific and social interest on this subject has increased substantially after the increasing pressure of public opinion.

The use of plants to decontaminate soils and waters has been developed only recently, the first reports appearing in the eighties, followed by more exhaustive articles during the nineties (Chaney 1983, Baker et al. 1994, Cunningham et al. 1995, Salt et al. 1995, Raskin et al. 1997). Much effort still has to be directed towards an understanding of the basic mechanisms and towards improving knowledge of the applications (Marmiroli et al. 2006), but its usefulness has been demon- strated in many sites and this technology is now used by several environmental companies (Glass 2000).

Phytoremediation is based on the removal of contaminants from the soil by mechanisms such as phytoextraction, phytodegradation, rhizofiltration, phytostabilization and phytovolatilization (Salt et al. 1995), but the mechanisms involved in heavy metal remediation are limited to uptake, adsorption, transport and translocation, sequestration into vacuoles, hyperaccumulation and, in some cases, volatilization (Meagher 2000). Within this frame, studies on allocation plasticity and plant-metal partitioning can be of great significance (Audet \& Charest 2008). When present at increased concentrations, both essential (copper, iron, manganese, molybdenum, zinc) and non-essential metals (e.g., cadmium, chromium, lead, mercury) are toxic. Mercury and selenium can also be converted by plants into a volatile form to release and dilute into the atmosphere. Heavy metals cannot be metabolized, therefore the only possible strategy to apply is their extraction from contaminated soil and transfer to the smaller volume of harvestable plants for their disposal (Salt et al. 1995, Kumar et al. 1995, Raskin et al. 1997, Padmavathiamma \& Li 2007); biomass can also be used in producing energy and, if economically profitable, metals can be eventually recovered (Zacchini et al. 2009).

It must be stressed that some processes can limit the efficacy of plants in phytoremediation, such as the availability of the toxic metal ions in the soil for root uptaking, their rate of translocation from roots to shoots and the level of tolerance, the rate of chemical transformation into less toxic compounds (Prasad 2003). At the basis, we find the mechanisms implicated in plant metal tolerance and homeostasis (reviewed by Clemens 2001). Remediation using plants may take longer than other technologies, but the most relevant limitation is that it is most suited to cases where contaminants are present at shallow levels within the root layer.

Phytoremediation technology has been recently extensively reviewed (Salt et al. 1998, Meagher 2000, Dietz \& Schnoor 2001, Barceló \& Poschenrieder 2003, Suresh \& Ravishankar 2004, Newman \& Reynolds 2005, Pilon-Smith \& Freeman 2006, Audet \& Charest 2007a) and several species have been classified as hyperaccumulators and extensively investigated (Reeves 1992, Peer et al. 2005). However, on a large scale, metal uptake by trees can be more effective, mainly because of a deeper root system and a greater yield of biomass (Greger \& Landberg 1999, Fischerová et al. 2006). High productivity and elevated uptake and transloca- 
tion of pollutants to the harvestable biomass are the basis for efficient in situ restoration by means of vascular plants (Lasat 2002, Pulford \& Dickinson 2005, Chaney et al. 2007).

Some woody species can be advantageously used also for phytoremediation of soils and groundwater from organic pollutants (Corseuil \& Moreno 2001) and hydrocarbons (Thompson et al. 1998, Yoon et al. 2006). The potential in phytoremediation of metal contaminated soils expressed by forest trees has been assessed for several species in recent years (Arduini et al. 1996, Pisano \& Rockwood 1997, Kozlov et al. 2000, Maurice \& Lagerkvist 2000, Prasad \& Freitas 2000, Kopponen et al. 2001, Rosselli et al. 2003, Pulford \& Watson 2003, French et al. 2006, Meers et al. 2007, Unterbrunner et al. 2007, Brunner et al. 2008, Domínguez et al. 2008). Resistance to metals often appears to be clone- or hybrid-specific rather than species-specific (Punshon \& Dickinson 1999).

Poplars are particularly suitable for remediation purposes (Dix et al. 1997, Burken \& Schnoor 1998, Schnoor 2000), having already been considered for trials on metal tolerance in in vivo (Lingua et al. 2005) and in vitro observations (Franchin et al. 2007). Salicaceae are also reported to grow even in severe soil conditions and to accumulate heavy metals (Pulford \& Watson 2003, Berndes et al. 2004). Many studies have thus been focused on the use of willows and poplars in phytoextraction (Riddell-Black 1994 Labreque et al. 1995, Bañuelos et al. 1999, Robinson et al. 2000, Aronsson \& Perttu 2001, Granel et al. 2002, Klang-Westin \& Perrtu 2002, Hammer et al. 2003, Vyslouzilová et al. 2003, Vervaeke et al. 2003, Madejou et al. 2004, Sebastiani et al. 2004, Kuzovkina et al. 2004, Robinson et al. 2005, Giachetti \& Sebastiani 2006, Dos Santos Utmazian et al. 2007, Wieshammer et al. 2007, Jensen et al. 2009). These species can be advantageously exploited in short rotation coppice cultures (SRC), a strategy whose application in phytoremediation presents interesting and economically promising perspectives (Scarascia-Mugnozza et al. 1997, Paulson et al. 2003, Laureysens et al. 2004a, Laureysens et al. 2004b, Rockwood et al. 2004, Dickinson \& Pulford 2005, Witters et al. 2009).

\section{Use of in vitro cultures for research on phytoremediation}

The inherent difficulties of experimenting on very large long-lived organisms such as forest trees, motivates the development of model systems. Besides the exploitation of hydroponic cultures, the in vitro model systems using shoot and cell cultures of plants demonstrated to be a useful tool for investigating efficiency of metal uptake and translocation (Castiglione et al. 2007). Cell and organ culture, in fact, as well as hydroponics, allow very fast accumulation of data in comparison with whole plant experiments under field conditions (Golan-Goldhirsh et al. 2004), and offer the advantage of testing the effects of contaminants under controlled conditions (Harms 1992). Hydroponic screening is often used to evaluate tolerance, accumulation and translocation in plants. Watson et al. (2003) demonstrated in Salix that results obtained in hydroponics and in field experiments are comparable. It is always advisable, however, to confirm data obtained by hydroponic tests by field performance trials. Using this technique, several studies have concerned, for instance, the response of willows to a metal cocktail (Watson et al. 1999) and of willows and poplars to the presence of cadmium (Šottníková et al. 2003, Lunácková et al. 2003, Dos Santos Utmazian et al. 2007, Zacchini et al. 2009), the response of a clone of Populus x euramericana to high concentrations of copper (Borghi et al. 2007), the mechanism of resistance to aluminium of Picea abies (Heim et al. 1999), the determination of the role of glutathione reductase metabolism in the defence of poplar (Populus deltoides x P. nigra) against high zinc concentration (Di Baccio et al. 2005).

As stated by Golan-Goldhirsh et al. (2004), the use of in vitro systems enables dissection of the complex system of plant, soil, and microbial interaction in order to evaluate the effect of stress factors on metabolism, specific enzymes and metabolites involved in plant response to the pollutant. For many woody species, moreover, the application of in vitro propagation techniques, allows for fast plant production and the application of promising genetic engineering programs (Confalonieri et al. 2003, Lyyra et al. 2006).

High concentration of zinc has been found to negatively affect the photosynthetic machinery in poplar: inhibition of adventitious root formation and leaf chlorosis indicated that the clone used was tolerant to external concentrations less than or equal to $1 \mathrm{mM}$ (Castiglione et al. 2007), while in Eucalyptus globulus moderate concentrations of this metal were shown to either enhance or have no effect on rooting (Schwambach et al. 2005). Phytoremediation potentials of poplar lines (Populus nigra and transgenic $P$. canescens) were investigated using in vitro leaf discs cultures and found that $\mathrm{Zinc}^{2+}$ was phytotoxic only at high concentrations $\left(10^{-2}\right.$ to $\left.10^{-1} \mathrm{M}\right)$ in all $P$. canescens lines, but P. nigra was more sensitive (Bittsanszky et al. 2005). Cadmium added to the culture medium was shown to reduce the fresh and dry weights and the shoot length of white birch, while root length was not affected (Fernández et al. 2008). Copper at a concentration of $0.05 \mathrm{mM}$, manganese at $0.80 \mathrm{mM}$, and zinc at $0.12 \mathrm{mM}$ showed a negative effect on shoot growth (number of shoots per explant and shoot length) in Ailanthus altissima, considered a fast-growing and contamination-resistant species (Gatti 2008). Zinc was found toxic in aspen (Populus tremula $\mathrm{x}$ tremuloides) cultures at $0.5 \mathrm{mM}$ concentration, while lead at the same concentration did not show toxic effects and was accumulated at $3500 \mu \mathrm{g}$ per $\mathrm{g}$ of biomass (KalisováSpirochová et al. 2003). In vitro studies were also developed to investigate the effects of high concentrations of zinc and copper on the biosynthesis and accumulation of polyamine in Populus alba (Franchin et al. 2007). On the basis of leaf symptoms, rate of adventitious root formation and ethylene production, it was found that $\mathrm{Zn}$ at $0.5-1 \mathrm{mM}$ concentration was transiently toxic, while at 2-4 mM was increasingly toxic. Free and conjugated putrescine and spermidine accumulated proportionally to toxicity; also $\mathrm{Cu}$ strongly reduced rooting already at $5 \mu \mathrm{M}$ and caused severe, dose-dependent toxicity symptoms (shoot chlorosis and necrosis) using concentrations up to $500 \mu \mathrm{M}$. In in vitro growing microshoots of Populus alba, the effect of high concentrations of cadmium, copper, zinc, and arsenic was investigated, showing differences in the response of different clones (Di Lonardo et al. 2011). Axenic poplar tumor cell cultures were tested for demonstrating the capability of taking up trichloroethylene (TCE) and degrading it to several known metabolic products (Newman et al. 1997), while poplar (Populus deltoides $\times P$. nigra $)$ in vitro culture has been used for developing mathematical models to define degradation pathways of nitramine compounds within plant cells (Mezzari et al. 2004). Metal tolerance was detected in a callus culture established from Acer rubrum seedlings growing in soil contaminated by zinc, cadmium, nickel and arsenic. A positive linear correlation was found between zinc resistance of callus and total $\mathrm{Zn}$ in soil beneath sampled trees, while no significant correlations were evidenced with the other metals (Watmough \& Hutchinson 1998). In Acer pseudoplatanus callus culture, $\mathrm{Cu}-, \mathrm{Zn}$ and Cd-resistance traits were identified in cell lines originating from trees at a site contaminated by these metals (Watmough \& Dickinson 1995). In vitro screenings were also used to investigate how several heavy metals affect pollen germination and tube elongation in Pinus resinosa (Chaney \& Strickland 1984) and to test the tolerance for $\mathrm{Zn}$ and $\mathrm{Cu}$ in mycorrhyzal isolates collected in an abandoned $\mathrm{Cu}$ mines, in view of their inoculation into Pinus sylvestris seedlings (Adriaensen et al. 2005). Combined micropropagation and hydroponic culture were used to study tolerance to copper and zinc in Betula pendula, finding that a seed-derived clone from a $\mathrm{Pb} / \mathrm{Zn}$-contaminated site showed more tolerance to $\mathrm{Cu}$ and $\mathrm{Zn}$ than bud- 
derived clones from a $\mathrm{Cu} / \mathrm{Ni}$-contaminated site or from an uncontaminated area (Utriainen et al. 1997).

\section{Role of endophytic bacteria and mychorrhizas in phytoremediation}

Bacteria living within plant tissues without causing disease are referred to as endophytes. Some of these have shown the capacity to enhance plant growth and resistance to biotic and abiotic stresses by various mechanisms (e.g., nitrogen fixation, production of phytohormones, solubilisation of minerals, etc.), therefore, recently attention has been focusing on the role of endophytic bacteria in phytoremediation (Selosse et al 2004, Newman \& Reynolds 2005). Endophytes have been inoculated and studied, e.g., in hybrid spruce (Chanway et al. 2000), lodgepole pine (Chanway \& Holl 1994a), Douglas-fir (Chanway \& Holl 1994b), poplar and willow. Based on their potential for remediation, three Pseudomonas strains were identified and tested in a clone of hybrid cottonwood (Populus trichocarpa x P. deltoides) (Germaine et al. 2004). A large part of the research on this subject has been deal with the activity of endophytes on hydrocarbons. For instance, in hybrid cottonwood a strain of the endophyte Rhizobium tropici was found active in the degradation of explosives (Doty et al. 2005), as well as a Methylobacterium strain isolated from hybrid poplar (Populus deltoides x P. nigra Van Aken et al. 2004a, 2004b); poplar endophytic bacteria have been engineered for enhancing thrichloroethylene degradation (Shim et al. 2000) and Taghavi et al. 2005 observed a horizontal gene transfer of a plasmid conferring toluene degradation.

Concerning specifically heavy metals, it has been observed that heavy metal resistant endophytes are present in various hyperaccumulator plants growing on heavy-metal contaminated soil (Rajkumar et al. 2009) Among herbaceous plants, e.g., shoot endophytes of Thlaspi goesingense were found more tolerant to high nickel concentration than the correspondent rhizospheric bacteria (Idris et al. 2004), endophytic bacteria of Nicotiana tabacum could reduce cadmium phytotoxicity (Mastretta et al. 2009), recombinant heavy-metal resistant endophytic bacteria were studied in Lolium perenne and Lupinus luteus (Lodewyckx et al. 2001) Among woody species, some isolates of hybrid cottonwoods have demonstrated tolerance to heavy metals (Moore et al. 2006); bacteria associated with $\mathrm{Zn} / \mathrm{Cd}$-accumulating Salix caprea have been studied regarding their potential to support heavy metal phytoextraction (Kuffner et al. 2010).

Arbuscular mychorrhizas are also well known to be involved in the metal uptake; their presence in the soil may significantly affect the plant response to metal stress
(Pawloska \& Charvat 2004). A vast amount of literature is available on the effects of mycorrhizal colonisation of plants living in heavy metal-polluted soils (Göhre \& Paszkowski 2006), on the protective role of mycorrhizas against heavy-metal induced oxidative stress (Schützendübel \& Polle 2002), and on their possible role in remediation (Khan et al. 2000, Audet \& Charest 2007b). In the hyperaccumulating fern Pteris vittata, for instance, they have been found to increase arsenic uptake (Trotta et al. 2006). Adriaensen et al. (2006) found that Pinus sylvestris seedlings colonized by a $\mathrm{Zn}$-tolerant isolate of Suillus bovinus grew much better and remained physiologically healthier when exposed to elevated $\mathrm{Zn}$ concentration than seedlings not inoculated or colonized by a $\mathrm{Zn}$-sensitive isolate. The response to high copper (Todeschini et al. 2007) and zinc (Lingua et al. 2008) concentration was studied on poplar clones inoculated with arbuscular mycorrhizal fungi, while in mycorrhyzed Betula spp. tolerance to zinc (Denny \& Wilkins 1987) and $\mathrm{Cu}$ and $\mathrm{Pb}$ accumulation (Bojarczuk \& Kieliszewska-Rokicka 2010) were studied. By X-ray microanalysis of heavy metals, it was found that, in mycorrhized Picea abies seedlings, extracellular complexation of $\mathrm{Cd}$ occurred predominantly in the Hartig net hyphae and both extracellular complexation and cytosolic sequestration of $\mathrm{Zn}$ occurred in the fungal tissue (Frey et al. 2000). The potential benefits of ectomycorrhizal fungi in protecting their host plants from metal contamination were also investigated by Blaudez et al. (2000) after testing thirty-nine ectomycorrhizal isolates for their tolerance to cadmium, copper, nickel and zinc. The potential of Salix viminalis and Populus x generosa for the phytoextraction of heavy metals, inoculated or not with the fungus Glomus intraradices, was recently assessed (Bissonnette et al. 2010), while in Eucalyptus globulus grown in Zn-contaminated soil, the improving potential of interactions between saprophytic and arbuscular micorrhizal fungi was investigated (Arriagada et al. 2010).

\section{Molecular biology and genetic engineering for phytoremediation}

Molecular biology and genetic engineering are being increasingly considered as effective tools for better understanding and improving the phytoremediation capability of plants, whose biological functions can now be analyzed in detail and partly modified. The metal resistance systems are better known in microorganisms (Silver 1996, Hall 2002, Silver \& Phung 2005); in plants only a few systems of metal tolerance and/or sequestration are sufficiently characterized (Kärenlampi et al. 2000). In recent years, several key steps have been identified at the molecular level, allowing an increasing ap- plication of molecular-genetic technologies and a transgenic approach to a better understanding of mechanisms involved in heavy metal tolerance and accumulation in plants (Clemens et al. 2002, Yang et al. 2005). It has been demonstrated in classic genetic studies that only a few genes are responsible for metal tolerance (Macnair et al. 2000). Transfer and/or overexpression of genes responsible for metal uptake, translocation and sequestration may allow for the production of plants which, depending on the strategy, can be successfully exploited in phytoremediation (Krämer \& Chardonnens 2001, Pilon-Smits \& Pilon 2002, Clemens et al. 2002, Rugh 2004, Eapen \& D'Souza 2005, Cherian \& Oliveira 2005, Doty 2008). In this case, special attention must be paid to problems related to the introduction of genetically modified trees, particularly concerning their legal and social acceptance (Knowles \& Adair 2007). Promotion of growth and biomass production is a correlated task accomplished, for instance, by increased gibberellin biosynthesis (Eriksson et al. 2000).

The improvement of the phytoremediation properties of plants can be achieved by the modification of their primary and secondary metabolism and the introduction of new phenotypic and genotypic characters (Davison 2005). Even if most of the genes involved in metal uptake, transport and sequestration have been studied on the herbaceous model plant Arabidopsis, it must be considered that this species, as well as the most common species defined as hyperaccumulators, have a limited phytoremediation capacity due to their small size or slow growth rate. On the contrary, large, fastgrowing plants, like some woody plants, are an important tool for this purpose; on poplars, for instance, reasonable transformation frequencies have been achieved (Han et al. 2000).

Studies on Arabidopsis and other species (hyperaccumulators), however, open the way to a transfer and application to high-biomass plants. Among these, Populus species (poplars, cottonwoods, aspens) and hybrids have become a model system in forest tree biotechnology (Bradshaw et al. 2000), due to several useful features: short rotation cycle, rapid growth rate and ease of vegetative propagation and in vitro multiplication (Confalonieri et al. 2003). Moreover, the poplar genome has been entirely sequenced (Tuskan et al. 2006). It is always important, however, to take into account the risks associated with the biotechnological applications and carefully evaluate the field performances of transgenic plants (Confalonieri et al. 2003).

Hairy roots induction by Agrobacterium rhizogenes is probably the easiest method for enhancing the root biomass and, consequently, improving metal uptake. This has been demonstrated for some hyperaccumu- 
lator plants (Maitani et al. 1996, Nedelkoska \& Doran 2000, Eapen et al. 2003, Eapen \& D'Souza 2005).

Transgenic white poplar has been recently obtained expressing the PSMTal gene from Pisum sativum for a metallothionein-like protein. Transformed plants showed enhanced resistance to heavy metal, surviving high concentrations of $\mathrm{CuCl}_{2}$ in in vitro culture, which strongly affected the nontransgenic plants. Rooting capacity of microshoots was maintained in transgenic lines exposed to $0.1 \mathrm{mM} \mathrm{CuCl}_{2}$, while it was totally destroyed in nontransgenic shoots. In the presence of $1 \mathrm{mM} \mathrm{ZnSO4,} \mathrm{nontrans-}$ formed shoots rooted abundantly, while different rooting rates were observed in transgenic lines (Balestrazzi et al. 2009).

Genes encoding enzymes changing the oxidation state of heavy metals can be introduced into plants (Rugh et al. 1996, Hansen et al. 1998). For instance, compared to wild type, transgenic Populus deltoides overexpressed mer- $A 9$ and mer-A18 genes, when grown in soil with high mercury concentration, developing higher biomass and higher amount of $\mathrm{Hg}(0)$, which evaporates through the cell surface (Che et al. 2003). Increased tolerance to ionic mercury was first obtained in yellow poplar (Lyriodendron tulipifera) transformed with mer-A gene (Rugh et al 1998). For the remediation of $\mathrm{Hg}$, Populus deltoides has been engineered with the bacterial mer- $A$ (mercuric ion reductase) and mer- $B$ (organomercurial lyase - Che et al. 2003); transgenic trees expressing both genes showed tolerance up to $10 \mu \mathrm{M}$ of phenylmercuric acetate (PMA - Lyyra et al. 2007). Significant results on tolerance to mercury and related remediation capacity were obtained also in Oryza sativa (Heaton et al. 2003) and in Spartina alterniflora (Czako et al. 2006). In Salix spp. it was proved that the majority of the mercury is accumulated and retained in the cell wall of the roots and only a very small part is transferred to the shoots (Wang \& Greger 2004).

Genetic engineering for arsenate reduction, increased translocation from root to shoot, and volatilisation has been recently illustrated and discussed (Zhu \& Rosen 2009). Arabidopsis has been transformed in order to better control the mobility and sequestration of arsenic (Dhankher et al. 2002). In Pteris vittata, genes have been identified that encode enzymes with arsenate reductive activity (Dhankher et al. 2002, Ellis et al. 2006, Rathinasabapathi et al. 2006).

For selenium, a strategy to protect protein synthesis from the activity of this metal was applied in transformed Arabidopsis by the expression of a mammalian selenocysteine lyase (Pilon et al. 2003) and could be now tested on woody species.

Transgenic poplar, with increased glutathione peroxidase activity, showed increased tolerance to zinc, probably due to an enhanced ability to detoxify the active oxygen species generated by the pollutant (Bittsanszky et al. 2005). Alterations in photosynthetic parameters and reduction in growth have been reported for a Populus x euramericana clone after treatment with high concentrations of zinc (Di Baccio et al. 2003).

Cadmium in the environment derives from industrial processes, urban pollution (heating systems and traffic), fertilizers and mineralization of rocks (Rauser \& Muwly 1995). Sensitivity to and accumulation of cadmium in some woody species have been recently studied in Sweden (Österås et al. 2000). In a relatively new strategy, aimed to compartmentalize the metals, tolerance to lead and cadmium was enhanced in Arabidopsis by the overexpression of the yeast vacuolar transporter protein YCF1 (Song et al. 2003), demonstrating the possibility to engineer phytoremediators for increasing their ability to sequester heavy metals. Poplars overexpressing a bacterial glutamylcysteine synthetase in the cytosol reached a 30-fold increase in its foliar activity compared to untransformed controls; this allowed greater tissue cadmium accumulation but had only a marginal effect on cadmium tolerance (Arisi et al. 2001)

Plant roots are able to release into the rizosphere chelating agents with binding ability for metals (Kinnersely 1993). These metal chelators or other molecules within plant cells that have a high affinity for metals can help in the metal sequestering (Grill et al. 1985, Mehra \& Tripathi 1999, Schat et al. 2002, Shah \& Nongkynrih 2007, Fulekar et al. 2009). Plants may also be engineered to enhance the synthesis of metal chelators (Kärenlampi et al. 2000, Clemens et al. 2002). Metal chelators include phytochelatins, metallothioneins, organic acids and amino acids. In vitro experiments have shown that cadmium in the form of phytochelatin complex is much better tolerated by plant enzyme than its free radical ion (Kneer \& Zenk 1992). In Nicotiana glauca transformed with a gene encoding a phytochelatin synthase, more metals were accumulated when grown in mine soils compared with non-transformed plants (Martinez et al. 2006). Attempts have been made to increase the formation of phytochelatins by overexpressing genes encoding enzymes stimulating the synthesis of cysteine and glutathione (Harada et al. 2001). Metallothioneins, a category of remarkable interest, are defined as low molecular mass cysteine-rich proteins that can bind heavy metals and may play a role in their intracellular sequestration. In the hybrid poplar genome, they form a multigene family and it has been hypothesised that they participate in the process of metal homeostasis and possibly in the process of tolerance (Kohler et al. 2004). Advances in understanding the regulation of phytochelatins biosynthesis and metallothioneins gene expression and their possible roles in heavy metal detoxification and homeostasis have been recently reviewed (Cobbett \& Goldsbrough 2002).

\section{Conclusions}

Phytoremediation of metal-polluted soil by plant phytoextraction is a technique attracting the interest of an increasing scientific community and the use of woody species, in particular, presents some aspects of relevance. Biotechnologies are surely powerful tools allowing to investigate and evaluate the potential of phytoremediation. As described in this paper, many fields of study are contributing to a rapid increase of our knowledge on the mechanisms involved. However, despite of the intensive research carried out in the last years on this topic, very few field trials demonstrated the technical feasibility and economic workability of the described approaches (Van Nevel et al. 2007). Indeed, most of the literature rarely provides information on the practical application of phytoremediation techniques.

Specialisation and fragmentation of research is probably real, but it should not be seen as a limit: every progress can contribute and converge to increase the possibility of an advantageous exploitation of woody plants for phytoremediation.

\section{References}

Adriaensen K, Vrålstad T, Noben JP, Vangronsveld J, Colpaert JV (2005). Copper adapted Suillus luteus, a symbiotic solution for pines colonising $\mathrm{Cu}$ mine spoil. Applied and Environmental Microbiology 71: 7279-7284. - doi: 10.1128/ AEM.71.11.7279-7284.2005

Adriaensen K, Vangronsveld J, Colpaert JV (2006). Zinc-tolerant Suillus bovinus improves growth of Zn-exposed Pinus sylvestris seedlings. Mycorrhiza 16: 553-558. - doi: 10.1007/s00572006-0072-7

Arduini I, Godbold DL, Onnis A (1996). Cadmium and copper uptake and distribution in Mediterranean tree seedlings. Physiologia Plantarum 97: 111-117. - doi: 10.1111/j.1399-3054.1996. tb00486.x

Arisi ACM, Mocquot B, Lagriffoul A, Mench M, Foyer CH, Jouanin L (2001). Responses to cadmium in leaves of transformed poplars overexpressing $\Gamma$-glutamylcysteine synthetase.Physiologia Plantarum 109 (2):143 -149. - doi: 10.1034/ j.1399-3054.2000.100206.x

Aronsson P, Perttu K (2001). Willow vegetation filters for wastewater treatment and soil remediation combined with biomass production. Forestry Chronicle 77: 293-299. [online] URL: http://pubs.nrc-cnrc.gc.ca/cgi-bin/rp/rp2_abst_f? tfc_tfc77293-2_77_ns_nf_tfc2-01

Arriagada C, Pereira G, García-Romera I, Ocampo JA (2010). Improved zinc tolerance in Eucalyptus globulus inoculated with Glomus deserti- 
cola and Trametes versicolor or Coriolopsis rigida. Soil Biology \& Biochemistry 42: 1181124. - doi: 10.1016/j.soilbio.2009.10.011

Audet P, Charest C (2007a). Heavy metal phytoremediation from a meta-analytical perspective. Environmental Pollution 147 (1): 231-237. - doi: 10.1016/j.envpol.2006.08.011

Audet P, Charest C (2007b). Dynamics of Arbuscular mycorrhyzal symbiosis in heavy metal phytoremediation: Meta-analytical and conceptual perspectives. Environmental Pollution 147 (3): 609-614. - doi: 10.1016/j.envpol.2006. 10.006

Audet P, Charest C (2008). Allocation plasticity and plant-metal partitioning: Meta-analytical perspectives in phytoremediation. Environmental Pollution 156 (2): 290-296. - doi: 10.1016/j.envpol.2008.02.010

Baker AJM, McGrath SP, Sidoli CMD, Reeves RD (1994). The possibility of in situ heavy metal decontamination of polluted soils using crops of metal-accumulating plants. Resources, Conservation and Recycling 11: 41-49. - doi: 10.1016/ 0921-3449(94)90077-9

Balestrazzi A, Botti S, Zelasco S, Biondi S, Franchin C, Calligari P, et al. (2009). . Expression of the $\mathrm{PsMT}_{\mathrm{A} 1}$ gene in white poplar engineered with the MAT system is associated with heavy metal tolerance and protection against 8-hydroxy-2'deoxyguanosine mediated-DNA damage. Plant Cell Reports 28: 1179-1192. - doi: 10.1007/ s00299-009-0719-x

Bañuelos GS, Shannon MC, Ajwa H, Draper JH, Jordahl J, Licht L (1999). Phytoextraction and accumulation of boron and selenium by poplar (Populus) clones. International Journal of Phytoremediation 1: 81-96. - doi: 10.1080/ 15226519908500006

Barceló J, Poschenrieder C (2003). Phytoremediation: principles and perspectives. Science 2 (3): 333-344. [online] URL: http://publicacions.iec.cat/repository/pdf/00000022/00000097.pdf

Berndes G, Fredrikson F, Borjesson P (2004). Cadmium accumulation and Salix-based phytoextraction on arable land in Sweden. Agriculture, Ecosystems \& Environment 103: 207-223. - doi: 10.1016/j.agee.2003.09.013

Bissonnette L, St-Arnaud M, Labreque M (2010). Phytoextraction of heavy metals by two Salicaceae clones in symbiosis with arbuscular mycorrhizal fungi during the second year of a field trial. Plant and Soil 332: 55-67. - doi: 10.1007/s11104-009-0273-x

Bittsanszky A, Komives T, Gullner G, Gyulai G, Kiss J, Heszky L, Radimszky L, Rennenberg H (2005). Ability of transgenic poplars with elevated glutathione content to tolerate $\operatorname{zinc}(2+)$ stress. Environment International 31: 251-254. doi: 10.1016/j.envint.2004.10.001

Blaudez D, Jacob C, Turnau K, Colpaert JV, Ahonen-Jonnarth U, Finlay R, et al. (2000). Differential responses of ectomycorrhizal fungi to heavy metals in vitro. Mycological Research 104: 1366-1371. - doi: 10.1017 S0953756200003166

Bojarczuk K, Kieliszewska-Rokicka B (2010). Ef- fect of ectomycorrhiza on $\mathrm{Cu}$ and $\mathrm{Pb}$ accumulation in leaves and roots of silver birch (Betula pendula Roth.) seedlings grown in metal-contaminated soil. Water, Air and Soil Pollution 207: 227-240. - doi: 10.1007/s11270-009-0131-8 Borghi M, Tognetti R, Monteforti G, Sebastiani L (2007). Responses of Populus x euramericana (P. deltoides x P. nigra) clone Adda to increasing copper concentrations. Environmental and Experimental Botany 61: 66-73. - doi: 10.1016/j.envexpbot.2007.03.001

Bradshaw HD, Ceulemans R, Davis J, Stettler R (2000). Emerging model systems in plant biology: poplar (Populus) as a model forest tree. Journal of Plant Growth Regulation 19: 306-313. - doi: 10.1007/s003440000030

Brunner I, Luster J, Günthardt-Goerg MS, Frey B (2008). Heavy metal accumulation and phytostabilisation potential of tree fine roots in a contaminated soil. Environmental Pollution 152 (3): 559-568. - doi: 10.1016/j.envpol.2007.07.006

Burken JG, Schnoor JL (1998). Predictive relationships for uptake of organic contaminants by hybrid poplar trees. Environmental Science \& Technology 32 (21): 3379-3385. - doi: 10.1021/ es9706817

Castiglione S, Franchin C, Fossati T, Lingua G, Torrigiani P, Biondi S (2007). High zinc concentrations reduce rooting capacity and alter metallothionein gene expression in white poplar ( $\mathrm{PO}$ pulus alba L. cv. Villafranca). Chemosphere 67 (6): 1117-1126. - doi: 10.1016/j.chemosphere. 2006.11.039

Chaney RL (1983). Plant uptake of inorganic waste constitutes In: "Land treatment of hazardous wastes" (Parr JF, Marsh PB, Kla JM eds). Noyes Data Corp., Park Ridge, USA, pp. 50-76. Chaney RL, Angle JS, Broadhurst CL, Peters CA, Tappero RV, Sparks DL (2007). Improved understanding of hyperaccumulation yields commercial phytoextraction and phytomining technologies. Journal of Environmental Quality 36 (5): 1429-4143. - doi: 10.2134/jeq2006.0514

Chaney WR, Strickland RC (1984). Relative toxicity of heavy metals to red pine pollen germination and germ tube elongation. Journal of Environmental Quality 13: 391-394. - doi: 10.2134/ jeq1984.00472425001300030014x

Chanway CP, Shishido M, Nairn J, Jungwirth S, Markham J, Xiao G, Holl FB (2000). Endophytic colonization and field responses of hybrid spruce seedlings after inoculation with plant growthpromoting rhizobacteria. Forest Ecology and Management 133: 81-88. - doi: 10.1016/S03781127(99)00300-X

Chanway CP, Holl FB (1994a). Growth of outplanted lodgepole pine seedlings one year after inoculation with plant growth promoting rhizobacteria. Forest Science 40 (2): 238-246. [online] URL: http://www.ingentaconnect.com/ content/saf/fs/1994/00000040/00000002/art0000 4

Chanway CP, Holl FB (1994b). Ecological growth response specificity of two Douglas-fir ecotypes inoculated with coexistent beneficial rhizosphere bacteria. Canadian Journal of Botany 72 (5):
582-586. - doi:10.1139/b94-077

Che D, Meagher RB, Heaton ACP, Lima A, Rugh CL, Merkle SA (2003). Expression of mercuric ion reductase in Eastern cottonwood (Populus deltoides) confers mercuric ion reduction and resistance. Plant Biotechnology Journal 1: 311. doi: 10.1046/j.1467-7652.2003.00031.x

Cherian S, Oliveira MM (2005). Transgenic plants in phytoremediation: recent advances and new possibilities. Environmental Science \& Technology 39: 9377-9390. - doi: 10.1021/es0511341

Clemens S (2001). Molecular mechanisms of plant metal tolerance and homeostasis. Planta 212: 475-486. - doi: 10.1007/s004250000458

Clemens S, Palmgren MG, Kranmer U (2002). A long way ahead: understanding and engineering plant metal accumulation. Trends in Plant Science 7: 309-314. - doi: 10.1016/S1360-1385(02) 02295-1

Cobbett C, Goldsbrough P (2002). Phytochelatins and metallothioneins: roles in heavy metal detoxification and homeostasis. Annual Review of Plant Biology 53: 159-182. - doi: 10.1146/annurev.arplant.53.100301.135154

Confalonieri M, Balestrazzi A, Bisoffi S, Carbonera D (2003). In vitro culture and genetic engineering of Populus spp.: synergy for forest tree improvement. Plant Cell Tissue and Organ Culture 72: 109-138. - doi: 10.1023/A: 1022265504775

Corseuil HX, Moreno FN (2001). Phytoremediation potential of willow trees for aquifers contaminated with ethanol-blended gasoline. Water Research 35 (12): 3013-3017. - doi: 10.1016/ S0043-1354(00)00588-1

Cunningham SD, Berti WR, Huang JW (1995). Phytoremediation of contaminated soils. Trends in Biotechnology 13 (9): 393-397. - doi: 10.1016/ S0167-7799(00)88987-8

Czako M, Feng X, He Y, Liang D, Marton L (2006). Transgenic Spartina alterniflora for phytoremediation. Environmental Geochemistry and Health 28: 103-110. - doi: 10.1007/s10653-0059019-8

Davison J (2005). Risk mitigation of genetically modified bacteria and plants designed for bioremediation. Journal of Industrial Microbiology and Biotechnology 32: 639-650. - doi: 10.1007/ s10295-005-0242-1

Denny HJ, Wilkins DA (1987). Zinc tolerance in Betula spp. IV. Mechanisms of ectomycorrhizal amelioration of zinc toxicity to higher plants. New Phytologist 106: 545-553. [online] URL: http://www.jstor.org/pss/2434819

Dhankher OP, Li Y, Rosen BP, Shi J, Salt D, Senecoff JF, Sashti NA, Meagher RB (2002). Engineering tolerance and hyperaccumulation of arsenic in plants by combining arsenate reductase and gamma-glutamylcysteine synthetase expression. Nature Biotechnology 20: 1140-1141. - doi: 10.1038/nbt747

Di Baccio D, Tognetti R, Sebastiani L, Vitagliano C (2003). Responses of Populus deltoides $\times$ Populus nigra (Populus $\times$ euramericana) clone I214 to high zinc concentrations. New Phytologist 159: 443-451. - doi: 10.1046/j.1469-8137.2003. 
00818.x

Di Baccio D, Kopriva S, Sebastiani L, Rennenberg H (2005). Does glutathione metabolism have a role in the defence of poplar against zinc excess? New Phytologist 167: 73-80. - doi: 10.1111/j. 1469-8137.2005.01462.x

Dickinson NM, Pulford ID (2005). Cadmium phytoextraction using short-rotation coppice Salix: The evidence trail. Environment International 31: 609-613. - doi: 10.1016/j.envint.2004. 10.013

Dietz A, Schnoor JL (2001). Advances in phytoremediation. Environmental Health Perspectives 109: 163-168. - doi: 10.2307/3434854

Di Lonardo S, Capuana M, Arnetoli M, Gabbrielli R, Gonnelli C (2011). Exploring the metal phytoremediation potential of three Populus alba L. clones using an in vitro screening. Environmental Science \& Pollution Research 18: 82-90 doi: 10.1007/s11356-010-0354-7

Dix ME, Klopfenstein NB, Zhang JW, Workman SW, Kim MS (1997). Potential use of Populus for phytoremediation of environmental pollution in riparian zones. In: "Micropropagation, genetic engineering, and molecular biology of Populus, (Klopfenstein NB, Chun YW, Kim MS, Ahuja MR eds). Gen. Tech. Rep. RM-GTR-297, USDA Forest Service, pp. 206-211.

Domínguez MT, Marañón T, Murillo JM, Schulin R, Robinson BH (2008). Trace element accumulation in woody plants of the Guadiamar Valley, SW Spain: A large-scale phytomanagement case study. Environmental Pollution 152 (1): 50-59. doi: 10.1016/j.envpol.2007.05.021

Dos Santos Utmazian MN, Wieshammer G, Vega R, Wenzel WW (2007). Hydroponic screening for metal resistance and accumulation of cadmium and zinc in twenty clones of willows and poplars. Environmental Pollution 148: 155-165. doi: 10.1016/j.envpol.2006.10.045

Doty SL (2008). Enhancing phytoremediation through the use of transgenics and endophytes. New Phytologist 179: 318-333. - doi: 10.1111/j. 1469-8137.2008.02446.x

Doty SL, Dosher MR, Singleton G, Moore AL, Van Aken B, Stettler RF, et al. (2005). Identification of an endophytic Rhizobium in stems of Populus. Symbiosis 39: 27-36. [online] URL: http://cat.inist.fr/?aModele $=$ afficheN\&cpsidt $=$ 17006331

Dudka S, Miller WP (1999). Accumulation of potentially toxic elements in plants and their transfer to human food chain. Journal of Environmental Science and Health 34 (4): 681-708. - doi: 10.1080/03601239909373221

Eapen S, Suseelan K, Tivarekar S, Kotwal S, Mitra R (2003). Potential for rhizofiltration of uranium using hairy root cultures of Brassica juncea and Chenopodium amaranticolor. Environmental Research 91: 127-133. - doi: 10.1016/ S0013-9351(02)00018-X

Eapen S, D'Souza SF (2005). Prospects of genetic engineering of plants for phytoremediation of toxic metals. Biotechnoligal Advances 23: 97114. - doi: 10.1016/j.biotechadv.2004.10.001 Ellis DR, Gumaelius L, Indriolo E, Pickering IJ,
Banks JA, Salt DE (2006). A novel arsenate reductase from the arsenic hyperaccumulating fern Pteris vittata. Plant Physiology 141: 1544-1554. - doi: 10.1104/pp.106.084079

Eriksson ME, Israelsson M, Olsson O, Moritz T (2000). Increased giberellin biosynthesis in transgenic trees promotes growth, biomass production and xylem fiber length. Nature Biotechnology 18: 784-788. - doi: 10.1038/77355

Fernández R, Bertrand A, Casares A, García R, González A, Tamés RS (2008). Cadmium accumulation and its effect on the in vitro growth of woody fleabane and mycorrhized white birch. Environmental Pollution 152 (3): 522-529. - doi: 10.1016/j.envpol.2007.07.011

Fischerová Z, Tlustos P., Szakova J, Sichorova K (2006). A comparison of phytoremediation capability of selected plant species for given trace elements. Environmental Pollution 144: 93-100. doi: 10.1016/j.envpol.2006.01.005

Franchin C, Fossati T, Pasquini E, Lingua G, Castiglione S, Torrigiani P (2007). High concentrations of $\mathrm{Zn}$ and $\mathrm{Cu}$ induce differential polyamine responses in micropropagated white poplar (Populus alba L. 'Villafranca'), Physiologia Plantarum 130: 77-90. - doi: 10.1111/j.1399-3054.2007. 00886.x

French CJ, Dickinson NM, Putwain PD (2006). Woody biomass phytoremediation of contaminated brownfield land. Environmental Pollution 141: 387-395. - doi: 10.1016/j.envpol.2005.08. 065

Frey B, Zierold K, Brunner I (2000). Extracellular complexation of $\mathrm{Cd}$ in the Hartig net and cytosolic $\mathrm{Zn}$ sequestration in the fungal mantle of Picea abies-Hebeloma crustuliniforme ectomycorrhizas. Plant Cell \& Environment 23: 1257-1265. - doi: 10.1046/j.1365-3040.2000.00637.x

Fulekar MH, Singh A, Bhaduri AM (2009). Genetic engineering strategies for enhancing phytoremediation of heavy metals. African Journal of Biotechnology 8 (4): 529-535.

Gatti E (2008). Micropropagation of Ailanthus altissima and in vitro heavy metal tolerance. Biologia Plantarum 52 (1): 146-148. - doi: 10.1007/ s10535-008-0030-7

Germaine K, Keogh E, Garcia-Cabellos G, Borremans B, van der Lelie D, Barac T, et al. (2004). Colonisation of poplar trees by $g$ fpexpressing bacterial endophytes. FEMS Microbiology Ecology 48: 109-118. - doi: 10.1016/j.femsec.2003. 12.009

Giachetti G, Sebastiani L (2006). Metal accumulation in poplar plant grown with industrial wastes. Chemosphere 64: 446-454. - doi: 10.1016/j.chemosphere.2005.11.021

Glass DJ (2000). Economic potential of phytoremediation. In: "Phytoremediation of toxic metals, using plants to clean up the environment" (Raskin I, Ensley BD eds). John Wiley, New York, USA, pp. 15-31.

Golan-Goldhirsh A, Barazani O, Nepovim A, Soudek P, Smrcek S, Dufkova L, et al. (2004). Plant response to heavy metals and organic pollutants in cell culture and at whole plant level. Journal of Soils and Sediments 4 (2): 133-140. - doi: 10.1007/BF02991058

Göhre V, Paszkowski U (2006). Contribution of the arbuscular mycorrhizal symbiosis to heavy metal phytoremediation. Planta 223 (6): 1115 1122. - doi: 10.1007/s00425-006-0225-0

Granel T, Robinson BH, Mills TM, Clothier BE, Green SR, Fung L (2002). Cadmium accumulation by willow clones used for conservation, stock fodder and phytoremediation. Australian Journal of Soil Research 40: 1331-1337. - doi: 10.1071/SR02031

Greger M, Landberg T (1999). Use of willow in phytoextraction. International Journal of Phytoremediation 1: 115-123. - doi: 10.1080/ 15226519908500010

Grill E, Winnacker EL, Zenk MH (1985). Phytochelatins, the principal heavy-metal complexing peptides of higher plants. Science 230: 674-676. - doi: 10.1126/science.230.4726.674 Hall JL (2002). Cellular mechanisms for heavy metal detoxification and tolerance. Journal of Experimental Botany 366: 1-11. - doi: 10.1093/ jexbot/53.366.1

Hammer D, Kayser A, Keller C (2003). Phytoextraction of $\mathrm{Cd}$ and $\mathrm{Zn}$ with Salix viminalis in field trials. Soil Use and Management 19: $187-$ 192. - doi: 10.1111/j.1475-2743.2003.tb00303.x

Han KH, Meilan R, Ma C, Strauss SH (2000). An Agrobacterium tumefaciens transformation protocol effective on a variety of cottonwood hybrids (genus Populus). Plant Cell Reports 19: 315-320. - doi: 10.1007/s002990050019

Hansen D, Duda P, Zayed AM, Terry N (1998). Selenium removal by constructed wetlands: role of biological volatilization. Environmental Science \& Technology 32: 591-597. - doi: 10.1021/ es9705021

Harada E, Choi YE, Tsuchisaka A, Obata H, Sano $\mathrm{H}$ (2001). Transgenic tobacco plants expressing a rice cysteine synthase gene are tolerant to toxic levels of cadmium. Journal of Plant Physiology 158: 655-661. - doi: 10.1078/0176-1617-00314

Harms HH (1992). In vitro systems for studying phototoxicity and metabolic fate of pesticides and xenobiotics in plants. Pesticide Science 35: 277-281. - doi: 10.1002/ps.2780350313

Heaton ACP, Rugh CL, Kim T, Wang NJ, Meagher RB (2003). Toward detoxifying mercurypolluted aquatic sediments with rice genetically engineered for mercury resistance. Environmental Toxicology and Chemistry 22: 2940-2947. doi: 10.1897/02-442

Heim A, Luster J, Brunner I, Frey B, Frossard E (1999). Effects of aluminium treatment on Norway spruce roots, aluminium binding forms, element distribution, and release of organic acids. Plant and Soil 216 (1/2): 103-116. - doi: 10.1023/A:1004728122261

Idris R, Trifonova R, Puschenreiter M, Wenzel WW, Sessitsch A (2004). Bacterial communities associated with flowering plants of the Ni hyperaccumulator Thlaspi goesingense. Applied and Environmental Microbiology 70: 2667-277. doi: 10.1128/AEM.70.5.2667-2677.2004

Jensen JK, Holm PE, Nejrup J, Larsen MB, Borggaard OK (2009). The potential of willow 
for remediation of heavy metal polluted calcareous urban soils. Environmental Pollution 157: 931-937. - doi: 10.1016/j.envpol.2008.10. 024

Kalisová-Spirochová I, Puncochárová J, Kafka Z (2003). Accumulation of heavy metals by in vitro cultures of plants. Water, Air and Soil Pollution 3: 269-276. - doi: 10.1023/A: 1023933902452

Kärenlampi S, Schat H, Vangronsveld J, Verkleij JAC, Van der Lelie D, Mergeay M, et al. (2000). Genetic engineering in the improvement of plants for phytoremediation of metal polluted soils. Environmental Pollution 107: 225-231. doi: 10.1016/S0269-7491(99)00141-4

Khan AG, Keuk C, Chaudhry TM, Khoo CS, Hayes WJ (2000). Role of plants, mycorrhizae and phytochelators in heavy metal contaminated land remediation. Chemosphere 41: 197-207. doi: 10.1016/S0045-6535(99)00412-9

Kinnersely AM (1993). The role of phytochelates in plant growth and productivity. Plant Growth Regulation 12: 207-217. - doi: 10.1007/ BF00027200

Klang-Westin E, Perrtu K (2002). Effects of nutrient supply and soil cadmium contamination on cadmium removal by willow. Biomass \& Bioenergy 23: 415-426. - doi: 10.1016/S0961-9534 (02)00068-5

Kloke A, Sauerbeck DR, Vetter H (1984). The contamination of plants and soils with heavy metals and the transport of metals in terrestrial food chains. In: "Changing metal cycles and human health" (Nriagu JO ed). Springer-Verlag, Berlin, pp. 113-119.

Kneer R, Zenk MH (1992). Phytochelatins protect plant enzymes from heavy metal poisoning. Phytochemistry 31: 2663-2667. - doi: 10.1016/ 0031-9422(92)83607-Z

Knowles LP, Adair A (2007). Genetic engineering in trees: the international legal landscape. Journal of Biolaw and Business 10 (4): 16-22.

Kohler A, Blaudez D, Chalot M, Martin F (2004). Cloning and expression of multiple metallothioneins from hybrid poplar. New Phytologist 164: 83-93. - doi: 10.1111/j.1469-8137.2004. 01168.x

Kopponen P, Utriainen M, Lukkari K, Suntioinen S, Karenlampi L, Karenlampi S (2001). Clonal differences in copper and zinc tolerance of birch in metal-supplemented soils. Environmental Pollution 112: 89-97. - doi: 10.1016/S0269-7491 (00)00096-8

Kozlov MV, Haukioja E, Bakhtiarov AV, Stroganov DN, Zimina SN (2000). Root versus canopy uptake of heavy metals by birch in an industrially polluted area: contrasting behaviour of nickel and copper. Environmental Pollution 107 (3): 413-420. - doi: 10.1016/S0269-7491(99) 00159-1

Krämer U, Chardonnens AN (2001). The use of transgenic plants in the bioremediation of soils contaminated with trace elements. Applied Microbiology and Biotechnology 55: 661-72. - doi: 10.1007/s002530100631

Kuffner M, De Maria S, Puschenreiter M, Fall- mann K, Wieshammer G, Gorfer $M$, et al. (2010). Culturable bacteria from $\mathrm{Zn}$ - and Cdaccumulating Salix caprea with differential effects on plant growth and heavy metal availability. Journal of Applied Microbiology 108: 14711484. - doi: 10.1111/j.1365-2672.2010.04670.x

Kumar PBAN, Dushenkov V, Motto H, Raskin I (1995). Phytoextraction: The use of plants to remove heavy metals from soils. Environmental Science \& Technology 29: 1232-1238. - doi: 10.1021/es00005a014

Kuzovkina YA, Knee M, Quigley MF (2004). Cadmium and copper uptake and translocation in five willow (Salix L.) species. International Journal of Phytoremediation 6: 269-287. - doi: 10.1080/16226510490496726

Labreque M, Teodorescu TI, Daigle S (1995). Effect of wastewater sludge on growth and heavy metal bioaccumulation of two Salix species. Plant and Soil 171: 303-316. - doi: 10.1007/ BF00010286

Lasat MM (2002). Phytoextraction of toxic metals: a review of biological mechanisms. Journal of Environmental Quality 31: 109-120. doi: $10.2134 /$ jeq2002.0109

Laureysens I, Blust R, De Temmerman L, Lemmens C, Ceulemans R (2004a). Clonal variation in heavy metal accumulation and biomass production in a poplar coppice culture: I. Seasonal variation in leaf, wood and bark concentrations. Environmental Pollution 131 (3): 485-494. - doi: 10.1016/j.envpol.2004.02.009

Laureysens I, Bogaert J, Blust R, Ceulemans R (2004b). Biomass production of 17 poplar clones in a short-rotation coppice culture on a waste disposal site and its relation to soil characteristics. Forest Ecology and Management 187 (2/3): 295309. - doi: 10.1016/j.foreco.2003.07.005

Lingua G, Castiglione S, Todeschini V, Franchin C, Fossati T, Peterson EA, et al. (2005). Selection of elite poplar clones for phytoremediation of soil contaminated by heavy metals in field and glass-house experiments. In: Proceedings of the "XVII International Botanical Congress". Wien (Austria) 17-23 July 2005, pp. 624.

Lingua G, Franchin C, Todeschini V, Castiglione S, Biondi S, Burlando B, et al. (2008). Arbuscular mycorrhizal fungi differentially affect the response to high zinc concentrations of two registered poplar clones. Environmental Pollution 153: 147-157. - doi: 10.1016/j.envpol.2007.07. 012

Lodewyckx C, Taghavi S, Mergeay M, Vangronsveld J, Clijsters H, van der Lelie D (2001). The effect of recombinant heavy metal resistant endophytic bacteria in heavy metal uptake by their host plant. International Journal of Phytoremediation 3: 173-187. - doi: 10.1080/15226510108 500055

Lunácková L, Ottníková A, Masarovicová E, Lux A, Streko V (2003). Comparison of cadmium effect on willow and poplar in response to different cultivation conditions. Biologia Plantarum 47: 403-411. - doi: 10.1023/B:BIOP.0000023884. 54709.09

Lyyra S, Lima A, Merkle SA (2006). In vitro re- generation of Salix nigra from adventitious shoots. Tree Physiology 26: 969-975. [online] URL: http://treephys.oxfordjournals.org/content/ 26/7/969.abstract

Lyyra S, Meagher RB, Kim T, Heaton A, Montello P, Balish RS, Merkle SA (2007). Coupling two mercury resistance genes in Eastern cottonwood enhances the processing of organomercury. Plant Biotechnology Journal 5: 254-262. - doi: 10.1111/j.1467-7652.2006.00236.x

Macnair MR, Tilstone GH, Smith SE (2000). The genetics of metal tolerance and accumulation in higher plants. In: "Phytoremediation of contaminated soil and water" (Terry N, Bañuelos G eds). Lewis Publications, Boca Raton, FL, USA, pp. 235-250.

Madejou P, Maranon T, Murillo JM, Robinson B (2004). White poplar (Populus alba) as a biomonitor of trace elements in contaminated riparian forests. Environmental Pollution 132: 145 155. - doi: 10.1016/j.envpol.2004.03.015

Maitani Y, Kubota H, Sato K, Takeda M, Yoshihira K (1996). Induction of phytochelatin (class III metallothionein) and incorporation of copper in transformed hairy roots of Rubia tinctorum exposed to cadmium. Journal of Plant Physiology 147: 743-748.

Marmiroli N, Marmiroli M, Maestri E (2006). Phytoremediation and phytotechnologies: a review for the present and the future. In: "Soil and water pollution monitoring, protection and remediation" (Twardowska I et al. eds). Springer, The Netherlands, pp. 3-23.

Martinez M, Bernal P, Almela C, Velez D, GarciaAgustin P, Serrano R, Navarro-Avino J (2006). An engineered plant that accumulates higher levels of heavy metals than Thlaspi caerulescens, with yields of 100 times more biomass in mine soils. Chemosphere 64: 478-485. - doi: 10.1016/ j.chemosphere.2005.10.044

Mastretta C, Taghavi S, van der Lelie D, Mengoni A, Galardi F, Gonnelli C, et al. (2009). Endophytic bacteria from seeds of Nicotiana tabacum can reduce cadmium phytotoxicity. International Journal of Phytoremediation 11: 251-267. - doi: 10.1080/15226510802432678

Maurice C, Lagerkvist A (2000). Using Betula pendula and Telephora caryophyllea for soil pollution assessment. Journal of Soil Contamination 9: 31-50. - doi: 10.1080/10588330091134185 Meagher RB (2000). Phytoremediation of toxic elemental and organic pollutants. Current Opinion in Plant Biology 3: 153-162. - doi: 10.1016/ S1369-5266(99)00054-0

McLaughlin MJ, Parker DR, Clarke JM (1999). Metals and micronutrients - food safety issues. Field Crops Research 60: 143-163. - doi: 10.1016/S0378-4290(98)00137-3

Meers E, Vandecasteele B, Ruttens A, Vangronsveld J, Tack FMG (2007). Potential of five willow species (Salix spp.) for phytoextraction of heavy metals. Environmental and Experimental Botany 60: 57-68. - doi: 10.1016/j.envexpbot. 2006.06.008

Mehra RK, Tripathi RD (1999). Phytochelatins and metal tolerance. In: "Environmental pollu- 
tion and plant responses" (Agrawal SB, Agrawal $M$ eds). CRC Press, Lewis Publisher, Boca Raton, FL, USA, pp. 367-382.

Mezzari MP, Van Aken B, Yoon JM, Just CL, Schnoor JL (2004). Mathematical modeling of RDX and HMX metabolism in poplar (Populus deltoides $\mathrm{x}$ Populus nigra, DN34) tissue culture. International Journal of Phytoremediation 6: 323345. - doi: 10.1080/16226510490888839

Moore FP, Barac T, Borremans B, Oeyen L, Vangronsveld J, van der Lelie D, et al. (2006). Endophytic bacterial diversity in poplar trees growing on a BTEX-contaminated site: the characterisation of isolates with potential to enhance phytoremediation. Systematic and Applied Microbiology 29 (7): 539-556. - doi: 10.1016/j.syapm.2005.11. 012

Nedelkoska TV, Doran PM (2000). Characteristics of heavy metal uptake by plant species with potential for phytoremediation and phytomining. Minerals Engineering 13: 549-561. - doi: 10.1016/S0892-6875(00)00035-2

Newman LA, Strand SE, Choe N, Duffy J, Ekuan G, Ruszaj M, et al. (1997). Uptake and biotransformation of trichloroethylene by hybrid poplars. Environmental Science \& Technology 31: 1062 1067. - doi: 10.1021/es960564w

Newman LA, Reynolds CM (2005). Bacteria and phytoremediation: new uses for endophytic bacteria in plants. Trends in Biotechnology 23: 6-8. doi: 10.1016/j.tibtech.2004.11.010

Österås AH, Ekvall L, Greger M (2000). Sensitivity to, and accumulation of, cadmium in Betula pendula, Picea abies, and Pinus sylvestris seedlings from different regions in Sweden. Canadian Journal of Botany 78 (11): 1440-1449. - doi: 10.1139/cjb-78-11-1440

Padmavathiamma PK, Li LY (2007). Phytoremediation technology: hyper-accumulation metals in plants. Water, Air and Soil Pollution 184: 105-126. - doi: 10.1007/s11270-007-9401-5

Paulson M, Bardos P, Harmsen J, Wilczek J, Barton M, Edwards D (2003). The practical use of short rotation coppice in land restoration. Land Contamination and Reclamation 11: 323-338. doi: 10.2462/09670513.624

Pawloska TE, Charvat I (2004). Heavy-metal stress and developmental patterns of arbuscular mycorrhizal fungi. Applied and Environmental Microbiology 70 (11): 6643-6649. - doi: 10.1128/AEM.70.11.6643-6649.2004

Peer WA, Baxter IR, Richards EL, Freeman JL, Murphy AS (2005). Phytoremediation and hyperaccumulator plants. In: "Molecular biology of metal homeostasis and detoxification, topics in current genetics" (Tamas M, Martinoia E eds). Vol. 14, Springer, Berlin, Germany, pp. 299-340. Pilon M, Owen JD, Garifullina GF, Kurihara T, Mihara H, Esaki N, Pilon-Smits EAH (2003). Enhanced selenium tolerance and accumulation in transgenic Arabidopsis expressing a mouse selenocysteine lyase. Plant Physiology 131: 1250-1257. - doi: 10.1104/pp.102.014639

Pilon-Smith EAH, Freeman JL (2006). Environmental cleanup using plants: biotechnological advances and ecological considerations. Frontiers in Ecology and the Environment 4: 203-210. doi: 10.1890/1540-9295(2006)004[0203:ECUPBA]2.0.CO;2

Pilon-Smits EAH, Pilon M (2002). Phytoremediation of metals using transgenic plants. Critical Revues in Plant Sciences 21: 439-456. - doi: 10.1080/0735-260291044313

Pisano SM, Rockwood DL (1997). Stormwater phytoremediation potential of Eucalyptus. In: Proceedings of the " 5 th Biennial Stormwater Research Conference". Tampa (Florida, USA) 5-7 November 1997. Water Management District, Brooksville, FL, USA, pp. 32-42.

Prasad MNV, Freitas H (2000). Removal of toxic metals from the aqueous solution by the leaf, stem and root phytomass of Quercus ilex L. (Holly Oak). Environmental Pollution 110 (2): 277-283. - doi: 10.1016/S0269-7491(99)00306-1 Prasad MNV (2003). Phytoremediation of metalpolluted ecosystems: hype for commercialization. Russian Journal of Plant Physiology 50: 686-700. - doi: 10.1023/A:1025604627496

Pulford ID, Watson C (2003). Phytoremediation of heavy metal-contaminated land by trees - A review. Environment International 29: 529-540. doi: 10.1016/S0160-4120(02)00152-6

Pulford ID, Dickinson NM (2005). Phytoremediation technologies using trees. In: "Trace elements in the environment" (Prasad MNV, Saiwan KS, Naidu R eds). Taylor and Francis, CRC Press, New York, USA, pp. 375-395.

Punshon T, Dickinson NM (1999). Heavy metal resistance and accumulation characteristics in willows. Internationl Journal of Phytoremediation 1: 361-385. - doi: 10.1080/ 15226519908500025

Puschenreiter M, Horak O, Friesl W, Hartl W (2005). Low-cost agricultural measures to reduce heavy metal transfer into food chain-a review. Plant, Soil and Environment 51: 1-11. [online] URL: http://www.cazv.cz/attachments/1-puschen reiter.pdf

Rajkumar M, Ae N, Freitas H (2009). Endophytic bacteria and their potential to enhance heavy metal phytoextraction. Chemosphere 77(2): 153160. - doi: 10.1016/j.chemosphere.2009.06.047

Raskin I, Smith RD, Salt DE (1997). Phytoremediation of metals: using plants to remove pollutants from the environment. Current Opinion in Biotechnology 8: 221-226. - doi: 10.1016/S09581669(97)80106-1

Rathinasabapathi B, Wu S, Sundaram S, Rivoal J, Srivastava M, Ma LQ (2006). Arsenic resistance in Pteris vittata L.: identification of a cytosolic triosephosphate isomerase based on cDNA expression cloning in Escherichia coli. Plant Molecular Biology 62: 845-857. - doi: 10.1007/ s11103-006-9060-8

Rauser WE, Muwly P (1995). Retention of cadmium in roots of maize seedlings. Role of complexation by phytochelatins and related thiol peptides. Plant Physiology 109: 195-202. - doi: 10.1104/pp.109.1.195

Reeves RD (1992). The hyperaccumulation of nickel by serpentine plants. In: "The vegetation of ultramafic (Serpentine) soils" (Baker AJM,
Proctor J, Reeves RD eds). Intercept Ltd, Andover, UK, pp. 253-277.

Renzoni A, Zino F, Franchi E (1998). Mercury levels along the food chain and risk for exposed populations. Environmental Research 77(2): 6872. - doi: 10.1006/enrs.1998.3832

Riddell-Black D (1994). Heavy metal uptake by fast growing willow species. In: "Willow vegetation filters for municipal wastewaters and sludges" (Aronsson P, Perttu K eds). Report no. 50, Sveriges Lantbruksuniversitet, Uppsala, pp. 145-151.

Robinson BH, Mills TM, Petit D, Fung LE, Green S, Clothier B, et al. (2000). Natural and induced cadmium-accumulation in poplar and willow: Implications for phytoremediation. Plant and Soil 227: 301-306. - doi: 10.1023/A:1026515007319 Robinson BH, Mills T, Green S, Chancerel B, Clothier B, Fung L, et al. (2005). Trace element accumulation by poplars and willows used for stock fodder. New Zealand Journal of Agricultural Research 48: 489-497. - doi: 10.1080/ 00288233.2005 .9513683

Rockwood DL, Naidu CV, Carter DR, Rahmani M, Spriggs TA, Lin C, et al. (2004). Short-rotation woody crops and phytoremediation: Opportunities for agroforestry? Agroforestry Systems 61: 51-63. - doi: 10.1023/B:AGFO.0000028989. 72186.e6

Rosselli W, Keller C, Boschi K (2003). Phytoextraction capacity of trees growing on a metal contaminated soil. Plant and Soil 256: 265-272. doi: 10.1023/A:1026100707797

Rugh CL (2004). Genetically engineered phytoremediation: one man's trash is another man's transgene. Trends in Biotechnology 22: 496-498. - doi: 10.1016/j.tibtech.2004.08.003

Rugh CL, Senecoff JF, Meagher RB, Merkle SA (1998). Development of transgenic yellow poplar for mercury phytoremediation. Nature Biotechnology 16: 925-928. - doi: 10.1038/nbt1098-925 Rugh CL, Wilde D, Stack NM, Thompson DM, Summers AO, Meagher RB (1996). Mercuric ion reduction and resistance in transgenic Arabidopsis thaliana plants expressing a modified bacterial merA gene. Proceedings of the National Academy of Science 93: 3182-3187. - doi: 10.1073/pnas.93.8.3182

Salt DE, Blaylock M, Nanda Kumar PBA, Dushenkov V, Ensley BD, Chet I, Raskin I (1995). Phytoremediation: a novel strategy for the removal of toxic metals from the environment using plants. Biotechnology 13: 468-474. doi: 10.1038/nbt0595-468

Salt DE, Smith RD, Raskin I (1998). Phytoremediation. Annual Review of Plant Physiology and Plant Molecular Biology 49: 643-668. - doi: 10.1146/annurev.arplant.49.1.643

Scarascia-Mugnozza G, Ceulemans R, Heilman PE, Isebrands JG, Stettler RF, Hinckley TM (1997). Production physiology and morphology of Populus species and their hybrids grown under short rotation. II. Biomass components and harvest index of hybrid and parental species clones. Canadian Journal of Forest Research 27: 285294. - doi: $10.1139 /$ cjfr-27-3-285 
Schat H, Llugany M, Vooijs R, Hartley-Whitaker J. Bleeker PM (2002). The role of phytochelatins in constitutive and adaptive heavy metal tolerances in hyperaccumulator and non-hyperaccumulator metallophytes. Journal of Experimental Botany 53: 1-12. - doi: 10.1093/jxb/erf107

Schnoor JL (2000). Phytostabilization of metals using hybrid poplar trees. In: "Phytoremediation of toxic metals, using plants to clean uup the environment" (Raskin I, Ensley BD eds). John Wiley, New York, USA, pp. 133-150.

Schützendübel A, Polle A (2002). Plant responses to abiotic stresses: heavy metal-induced oxidative stress and protection by mycorrhization. Journal of Experimantal Botany 53: 1351-1365. doi: $10.1093 /$ jexbot $/ 53.372 .1351$

Schwambach J, Fadanelli C, Fett-Neto AG (2005). Mineral nutrition and adventitious rooting in microcuttings of Eucalyptus globulus. Tree Physiology 25: 487-494. [online] URL: http://treephys.oxfordjournals.org/content/25/4/4 87.abstract

Sebastiani L, Scebba F, Tognetti R (2004). Heavy metal accumulation and growth responses in poplar clones Eridano (Populus deltoides $\times$ maximowiczii) and I-214 $(P$. $\times$ euramericana $)$ exposed to industrial waste. Environmental and $\mathrm{Ex}$ perimental Botany 52: 79-88. - doi: 10.1016/j.envexpbot.2004.01.003

Selosse MA, Baudoin E, Vandenkoornhuyse P (2004). Symbiotic microorganisms, a key for ecological success and protection of plants. Comptes Rendus Biologies 327: 639-648. - doi: 10.1016/j.crvi.2003.12.008

Shah K, Nongkynrih J (2007). Metal hyperaccumulation and bioremediation. Biologia Plantarum 51 (4): 618-634. - doi: 10.1007/s10535-0070134-5

Shim H, Chauhan S, Ryoo D, Bowers K, Thomas SM, Canada KA, et al. (2000). Rhizosphere competitiveness of trichloroethylene-degrading, poplar-colonizing recombinant bacteria. Applied and Environmental Microbiology 66: 4673-4678. doi: 10.1128/AEM.66.11.4673-4678.2000

Silver S (1996). Bacterial resistances to toxic metal ions - a review. Gene 179: 9-19. - doi: 10.1016/S0378-1119(96)00323-X

Silver S, Phung LT (2005). A bacterial view of the periodic table: genes and proteins for toxic inorganic ions. Journal of Industrial Microbiology and Biotechnology 32: 587-605. - doi: 10.1007/ s10295-005-0019-6

Song WY, Sohn EJ, Martinoia E, Lee YJ, Yang YY, Jasinski M, et al. (2003). Engineering tolerance and accumulation of lead and cadmium in transgenic plants. Nature Biotechnology 21: 914 919. - doi: 10.1038/nbt850

Šottníková A, Lunácková L, Masarovicová E, Lux A, Streško V (2003). Changes in the rooting and growth of willow and poplars induced by cadmium. Biologia Plantarum 46: 129-131. - doi: 10.1023/A:1022395118998

Suresh B, Ravishankar GA (2004). Phytoremediation - A novel a promising approach for environmental clean-up. Critical Revues in Biotechnology 24: 97-124. - doi: 10.1080/073885504
90493627

Taghavi S, Barac T, Greenberg B, Borremans B, Vangronsveld J, van der Lelie D (2005). Horizontal gene transfer to endogenous endophytic bacteria from poplar improves phytoremediation of toluene. Applied and Environmental Microbiology 71: 8500-8505. - doi: 10.1128/AEM.71. 12.8500-8505.2005

Thompson PL, Ramer LA, Schnoor JL (1998). Uptake and transformation of TNT by hybrid poplar trees. Environmental Science \& Technology 32: 975-980. - doi: 10.1021/es970799n

Todeschini V, Franchin C, Castiglione S, Burlando B, Biondi S, Torrigiani P, et al. (2007). Responses of two registered poplar clones to copper, after inoculation, or not, with arbuscular mycorrhizal fungi. Caryologia 60: 146-155.

Trotta A, Falaschi P, Cornara L, Minganti V, Fusconi A, Drava G, Berta G (2006). Arbuscular mycorrhizae increase the arsenic translocation factor in the As hyperaccumulating fern Pteris vittata L. Chemosphere 65: 74-81. - doi: 10.1016/j.chemosphere.2006.02.048

Tuskan GA, Di Fazio S, Jansson S, Bohlmann J, Grigoriev I, Hellsten U, et al. (2006). The genome of black cottonwood, Populus trichocarpa (Torr. \& Gray). Science 313: 1596-1604. - doi: 10.1126/science. 1128691

Unterbrunner R, Puschenreiter M, Sommer P, Wieshammer G, Tlustos $\mathrm{P}$, Zupan $\mathrm{M}$, et al. (2007). Heavy metal accumulation in tree growing on contaminated sites in Central Europe. Environmental Pollution 148: 107-114. - doi: 10.1016/j.envpol.2006.10.035

Utriainen MA, Kärenlampi LV, Kärenlampi SO, Schat H (1997). Differential tolerance to copper and zinc of micropropagated birches tested in hydroponics. New Phytologist 137: 543-549. - doi: 10.1046/j.1469-8137.1997.00840.x

Van Aken B, Peres CM, Doty SL, Yoon JM, Schnoor JL (2004a). Methylobacterium populi sp. nov., a novel aerobic, pink-pigmented, facultatively methylotrophic, methane-utilizing bacterium isolated from poplar trees (Populus deltoids $\times$ nigra DN34). International Journal of Systematic and Evolutionary Microbiology 54: 1191-1196. - doi: 10.1099/ijs.0.02796-0

Van Aken B, Yoon JM, Schnoor JL (2004b). Biodegradation of nitro-substituted explosives 2.4.6trinitrotoluene, hexahydro-1.3.5-trinitro-1.3.5triazine, and octahydro-1.3.5.7-tetranitro-1.3.5tetrazocine by a phytosymbiotic Methylobacteriumsp. associated with poplar tissues (Populus deltoides $\times$ nigra DN34). Applied and Environmental Microbiology 70: 508-517. - doi: 10.1128/AEM.70.1.508-517.2004

Van Nevel L, Mertens J, Oorts K, Verheyen K (2007). Phytoextraction of metals from soils: How far from practice. Environmental Pollution 150 (1): 34-40. - doi: 10.1016/j.envpol.2007. 05.024

Vervaeke P, Luyssaert S, Mertens J, Meers E, Tack FMG, Lust N (2003). Phytoremediation prospects of willow stands on contaminated sediment: a field trial. Environmental Pollution 126: 275-282. - doi: 10.1016/S0269-7491(03)00189-1
Vyslouzilová M, Tlustoš P, Száková J, Pavlíková D (2003). As, Cd, Pb and Zn uptake by Salix spp. clones grown in soils enriched by high loads of these elements. Plant, Soil and Environment 49: 191-196. [online] URL: http://www.cazv.cz/ 2003/PSE5_03/1-vyslouzilova.pdf

Wang Y, Greger M (2004). Clonal differences in mercury tolerance, accumulation, and distribution in willow. Journal of Environmental Quality 33 (5): 1779-1785. - doi: 10.2134/jeq2004.1779 Watmough SA, Dickinson NM (1995). Multiple metal resistance and co-resistance in Acer pseudoplatanus L. (sycamore) callus cultures. Annals of Botany 76: 465-472. - doi: 10.1006/ anbo.1995.1121

Watmough SA, Hutchinson TC (1998). Relationship between soil metal contamination and metal resistance of callus established from mature red maple. Canadian Journal of Forest Research 28 (7): 1073-1077. - doi: 10.1139/cjfr-28-7-1073

Watson C, Pulford ID, Riddell-Black D (1999). Heavy metal toxicity responses of two willow (Salix) varieties grown hydroponically: development of a tolerance screening test. Environmental Geochemistry and Health 21: 359-364. - doi: 10.1023/A:1006796720300

Watson C, Pulford ID, Riddell-Black D (2003). Screening of willow species for resistance to heavy metals: Comparison of performance in a hydroponics system and field trials. International Journal of Phytoremediation 5: 351-365.

Wieshammer G, Unterbrunner R, Garcia TB, Zivkovic MF, Puschenreiter M, Wenzel WW (2007). Phytoextraction of $\mathrm{Cd}$ and $\mathrm{Zn}$ from agricultural soils by Salix spp. and intercropping of Salix caprea and Arabidopsis halleri. Plant and Soil 298: 255-264. - doi: 10.1007/s11104-0079363-9

Witters N, Van Slycken S, Ruttens A, Adriaensen K, Meers E, Meiresonne L, et al. (2009). Shortrotation coppice of willow for phytoremediation of a metal-contaminated agricultural area: a sustainability assessment. BioEnergy Research 2 (3): 144-152. - doi: 10.1007/s12155-009-9042-1 Yang X, Feng Y, He Z, Stoffella PJ (2005). Molecular mechanisms of heavy metal hyperaccumulation and phytoremediation. Journal of Trace Elements in Medicine and Biology 18: 339-353. - doi: 10.1016/j.jtemb.2005.02.007

Yoon JM, Van Aken B, Schnoor JL (2006). Leaching of contaminated leaves following uptake and phytoremediation of RDX, HMX, and TNT by poplar. International Journal of Phytoremediation 8 (1): 81-94. - doi: 10.1080/ 15226510500507128

Zacchini M, Pietrini F, Scarascia Mugnozza G, Iori V, Pietrosanti L, Massacci A (2009). Metal tolerance, accumulation and translocation in poplar and willow clones treated with cadmium in hydroponics. Water, Air and Soil Pollution 197: 23-34. - doi: 10.1007/s11270-008-9788-7

Zhu YG, Rosen BP (2009). Perspectives for genetic engineering for the phytoremediation of arsenic-contaminated environments: from imagination to reality? Current Opinion in Biotechnology 20: 220-224. - doi: 10.1016/j.copbio.2009.02.011 